This item was submitted to Loughborough's Research Repository by the author.

Items in Figshare are protected by copyright, with all rights reserved, unless otherwise indicated.

\title{
Assessing the business value of mobile terminals in a UK police context
}

PLEASE CITE THE PUBLISHED VERSION

http://www.vathek.com/pj/

PUBLISHER

Vathek Publishing (@ the authors)

LICENCE

CC BY-NC-ND 4.0

\section{REPOSITORY RECORD}

Lindsay, Rachael, Thomas Jackson, and Louise Cooke. 2019. "Assessing the Business Value of Mobile Terminals in a UK Police Context”. figshare. https://hdl.handle.net/2134/11764. 
This item was submitted to Loughborough's Institutional Repository (https://dspace.lboro.ac.uk/) by the author and is made available under the following Creative Commons Licence conditions.

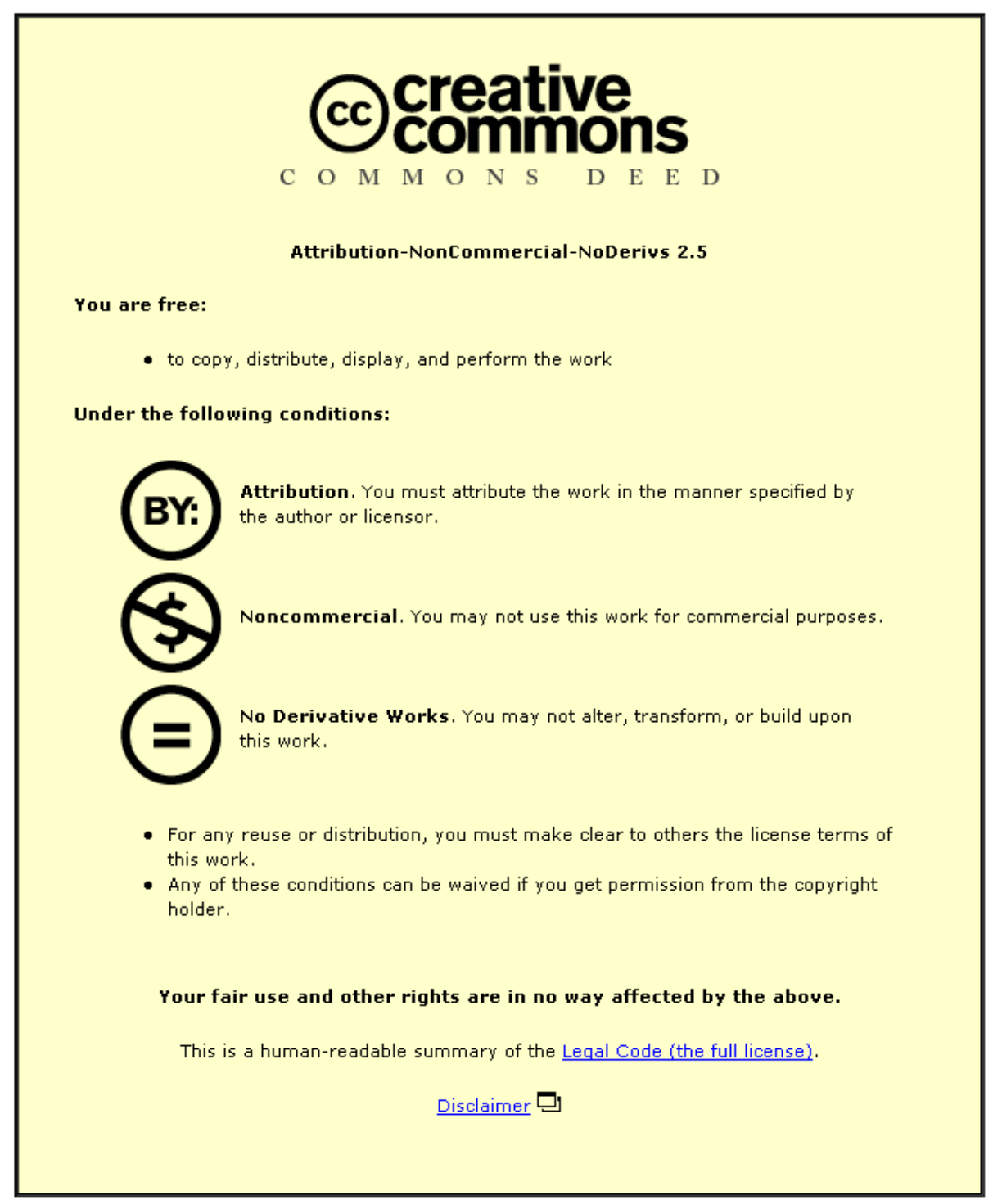

For the full text of this licence, please go to: http://creativecommons.org/licenses/by-nc-nd/2.5/ 


\title{
ASSESSING THE BUSINESS VALUE OF MOBILE TERMINALS \\ IN A UK POLICE CONTEXT
}

\author{
Dr. Rachael Lindsay ${ }^{a}$, Dr. Thomas W. Jackson ${ }^{a *}$ and Dr. Louise Cooke ${ }^{a}$ \\ ${ }^{a}$ Department of Information Science, Loughborough University, Loughborough, \\ Leicestershire, United Kingdom, LE11 3TU. \\ * Corresponding author. Email addresses: t.w.jackson@lboro.ac.uk
}

\begin{abstract}
In a climate of financial austerity, greater emphasis is placed on improving the operational effectiveness, efficiency and cost of delivery of services. This paper discusses the development of a conceptual framework to assess the business value and impact of mobile technologies in a UK police force. At present there are few structured frameworks from which police forces can assess the value of mobile technologies within a short time frame with little effort or large budget. The conceptual framework contributes to the performance assessment in policing, providing a structured approach for police forces to understand where to concentrate their efforts, in terms of which data to collect. It utilises secondary data sources, such as global positioning based resource and demand systems to assess impact on time spent policing communities. The conceptual framework can be used by police forces, and similar types of organisations, seeking assessment of new technological initiatives.
\end{abstract}

\subsection{Introduction}

Public administration is now focusing on performance improvement and providing better value for money to the taxpayer (Boyne et al, 2004; Pollitt and Bouckaert, 2000). Outcomes reporting is becoming more important to funders and governments as the demand for accountability continues to rise (Madan, 2007). As a result, UK police forces are facing increased levels of scrutiny into their expenditure. They are expected to respond to an increased demand for improvements in police efficiency in the context of decreasing levels of financial resources (Barton and Barton, 2011; Ilston, 2010). In recognition of this, an important review of policing made a number of proposals to address such considerable challenges, stating that: 'a leaner approach to policing is required, with the greater use of technology, particularly mobile technology, to free up Police time' (Flanagan, 2008, p. 9). Subsequently, £75 million of UK taxpayer monies was invested into a mobile information initiative to provide access to information regardless of geographical location and reduce inefficiencies associated with administering paper-based processes (Savvas, 2009; Home Office, 2008).

Difficulties in demonstrating the impact of such new initiatives lies in the attempts to develop appropriate methods of performance assessment (Collier, 2006; Barton and Barton, 2011). Inevitably, much of the work to date has focused on financial indicators, and although police forces must show that they have delivered a return on investment, sourced from the UK taxpayer, there are also other areas that must be considered. A large amount of performance measurement in policing has a narrow focus on activities arising from tasks related to policing functions, such as number of arrests and number of sick days, which are not true indicators of police effectiveness (Shane, 2010). As Wisniewski and 
Dickson (2001, p. 1060) comment: 'the approach to monitoring policing initiatives was to develop operational policing plans, for example for dealing with drunk driving, and to collect basic performance information usually focused on the more obvious outcomes such as number of arrests made. This short-sightedness meant that the problem was likely to resurface at some future time'. Whilst the importance of measuring performance in policing is recognised in previous research, there is little understanding or guidance in the literature to assess the impact of mobile technologies in the law enforcement domain. Thus an integrated framework to assess the value of the mobile information initiative with minimum effort, time and budget is required. The paper proposes a framework to enable an evaluation of the impact of the mobile initiative within the performance assessment process and discusses its development.

\subsection{Background}

The literature suggests that a large number of projects in the public sector are often abandoned or their funding is removed (Ward and Daniels, 2006). Boland and Fowler (2000) and Modell (2001) imply one reason for this is because performance measurement and evidencing success in the public sector have been poor. Performance measurement involves on going data collection to determine if a programme is implementing activities and achieving objectives over time (Office of Justice Programs, 2011). Despite the apparent importance of performance measurement, it has been suggested that attention has been centred on quantitative performance indicators, such as profit levels, percentage crime rates and value for money. It has been argued that a multi-dimensional approach to performance assessment is needed to broaden the focus from efficiency-based measures and reflect interests of a wider range of stakeholders, (Modell, 2001; Gomes et al, 2007).

In other cases, new initiatives can be assessed holistically through a range of planning, monitoring and evaluation (PME) methods. These represent a move away from traditional logical and linear evaluation of long-term widespread impact, to measuring fundamental changes in cultural behaviour (Smutylo, 2005). Amongst these methods are the Most Significant Change (MSC) technique, Logical Framework Analysis, Outcomes Based Accountability, the Balanced Scorecard and the Public Value Scorecard. The MSC technique excludes any measures per se and instead looks broader to collect significant change stories, which are reviewed and selected from the bottom to top levels of a project (Davies and Hart, 2005). However, this technique only looks back over a short, interim period and may imply that the 'most significant change' only seeks for positive outcomes. One of the most accepted methods of assessing outcomes is Logical Framework Analysis (LFA), developed by Practical Concepts Incorporated (Couillard et al, 2009). The process considers inputs, activities, outputs and outcomes. It can be used to aid structured and systematic analysis of a project or programme, to allow important questions to be asked, weaknesses identified and decision-makers can make informed decisions based on increased understanding of the project rationale (European Commission, 2004). Whilst it encourages a broader consideration towards the impact of a project on the end user and displays outputs in a single page, it requires a high level of investment in training and support to ensure that people use it.

Similarly, the Outcomes Based Accountability (OBA) approach is a conceptual framework to embed outcome-based decision-making into the planning process (Friedman, 2005). It starts with the ends to be achieved, in terms of improving quality of life, and works backwards as to how they can be delivered. The approach provides an alternative, flexible way to focus the work of the public sector organisations that are responsible for improving 
outcomes for individuals and communities. Like the LFA, OBA encourages managers to look beyond traditional means and consider the impact of their services on those who will use them. It also promotes shared accountability across authorities, organisations and communities for the well-being of a geographic population (Renshaw, 2006). Despite this, as Renshaw (2006) comments, it can be difficult to obtain baseline data at a community level to determine whether there has been a difference in outcomes. In addition, most public services lack experience in making credible forecasts of how the outcomes would develop if nothing were to change (Ibid.). Overall, OBA can be viewed as a collaborative planning tool to know whether agencies are making a difference to communities. Although OBA recognises the distinctive nature of the public sector, and may be useful in assessing the mobile project in a broader, non-financial sense, the project is beyond the planning phase to determine outcomes. Furthermore, little baseline data is available for the project. The core focus on the end user may also eliminate other metrics that are necessary to assess the mobile project.

The inadequacy of traditional measures is certainly recognised in the Balanced Scorecard (BSC). This aims to provide balanced information about corporate performance to management and emphasises the necessary relationship between measurement and strategy. It encompasses a more extensive range of metrics than the MSC, LFA and OBA and introduces three additional measurement perspectives to the financial measures of performance: customer satisfaction, internal processes and learning and innovation (Kaplan and Norton, 1992). The financial perspective remains at the top of the scorecard to represent its importance to profit-making organisations. Conversely, financial success is not the primary objective for most organisations in the public sector. As demonstrated by its application in the Dumfries and Galloway Police, when actions were translated across to the four scorecard perspectives, the financial perspective was empty (Wisniewski and Dickson, 2001). In addition, the customer perspective was felt to be too prescriptive given the difficulties of terminology within the police service and was renamed as the 'impact perspective' to give a wider focus to the community rather than specifically focusing on a group of customers (lbid.) Although Kaplan and Norton intended the BSC to be customisable to different organisations, research suggests that a tailored scorecard must be built for it to work in the public sector.

The limitations of the balanced scorecard in the public sector have been addressed to some extent by the development of the public value scorecard (PVS) by Moore (2003). This has the financial perspective swapped with the customer perspective acknowledging that customer satisfaction is central to the achievement of the public sector mission, and aligns better with a goal to contribute to society without emphasis on financial performance (Ibid.). The revised scorecard can be applied at different levels, such as for an organisation as a whole, specific departments, individual strategic initiatives and multiagency initiatives (Wisniewkski and Dickson, 2001). Further, the number of indicators used in performance measurement can cause information overload (Ibid.), yet this approach is believed to provide senior managers with a fast single report on organisational performance, compared with long reports or statistical analyses (Jashapara, 2004). The Dumfries and Galloway Constabulary used metrics that included the level of training and officer knowledge provided to officers, number of identified hotspots, the level of public involvement and number of incidents reported by the public. These metrics may offer a broader assessment of the performance of the Constabulary, rather than focusing measurement on costs and return on investment.

In contrast, some argue that the customer focus can blur rather than reinforce the outcomes focus, as there is too narrow a focus on customers instead of outcomes. 
Research by Gomes et al (2006) revealed that barriers to implementing the tool in policing include resistance to change, too great a focus on short-term problems and lack of a connection between the BSC and employees' rewards. The PVS also requires considerable time and effort to implement and demonstrate commitment from managers (Wisinewski and Olafsson, 2004). In terms of its applicability to the assessing the mobile information initiative, similar to other PME methods, the PVS provides a broader perspective than traditional financial measures but is tailored to suit public sector organisations such as policing. It can be applied to a single initiative, such as the mobile information project. Nevertheless, given the time and effort needed to implement the PVS, an alternative framework is needed, which incorporates elements from existing literature, to feasibly collect necessary evaluation data in a short time frame.

In the context of mobile policing, there are a broad range of metrics that are available to evaluate the initiative, as shown in Figure One. It is difficult for police forces to know which of these many metrics are practicable and how and where relevant data can be collected. The framework developed in this paper will assess the feasibility of each metric and provide a structured approach to collect sufficient data.

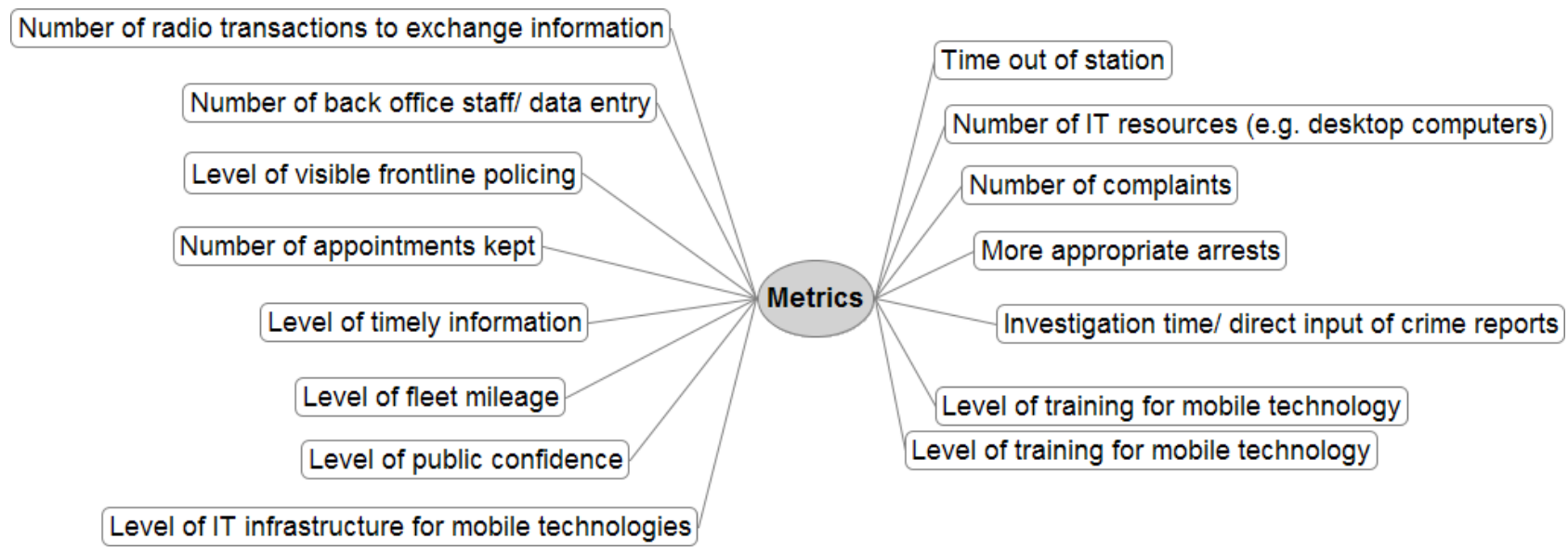

Figure 1: Broad range of metrics available to evaluate the mobile policing initiative, based on initial document analysis of police files and national guidance

Further explanation and justification of the methods used to assess the feasibility of each metric and to develop a structured framework are presented in the following section. The framework itself is presented in the results section, along with a discussion of its suitability and usefulness to the policing domain, and possibly other similar domains.

\subsection{Research Methods}

The two main research methods employed to develop the framework were Feasibility Analysis (via a document analysis) and secondary desk research. Table one summarises the research domain for each phase of the framework in terms of the method and sample employed. 
Table 1: Summary of the research domain deployed to develop the Framework

\begin{tabular}{|c|c|c|}
\hline Element of framework & $\begin{array}{l}\text { Method } \\
\text { employed }\end{array}$ & Sample/ Data \\
\hline $\begin{array}{l}\text { a) To identify and evaluate } \\
\text { specific metrics that can be } \\
\text { used to feasibly assess the } \\
\text { performance of mobile } \\
\text { technologies }\end{array}$ & $\begin{array}{l}\text { Feasibility } \\
\text { analysis } \\
\text { via a } \\
\text { document } \\
\text { analysis }\end{array}$ & $\begin{array}{l}\text { - Internal files and reports } \\
\text { relating to business benefits } \\
\text { - Internal and external email } \\
\text { communications } \\
\text { - Home Office documentation } \\
\text { and reports }\end{array}$ \\
\hline $\begin{array}{l}\text { b) To map these metrics to } \\
\text { their specific file locations and } \\
\text { propose a means of data } \\
\text { collection }\end{array}$ & $\begin{array}{l}\text { Information } \\
\text { map }\end{array}$ & Data used from element $A$. \\
\hline $\begin{array}{l}\text { c) To produce a template for a } \\
\text { balanced scorecard for } \\
\text { assessing the performance of } \\
\text { mobile technologies }\end{array}$ & $\begin{array}{l}\text { Literature } \\
\text { review }\end{array}$ & $\begin{array}{l}\text { Academic papers relating to } \\
\text { the application of the } \\
\text { balanced scorecard, } \\
\text { particularly within the public } \\
\text { sector, alongside metrics } \\
\text { selected from objective a. }\end{array}$ \\
\hline $\begin{array}{l}\text { d) To identify and analyse } \\
\text { specific data in relation to each } \\
\text { metric identified from objectives } \\
\text { one and two }\end{array}$ & $\begin{array}{l}\text { Desk } \\
\text { research }\end{array}$ & $\begin{array}{l}\text { Collate data from file locations } \\
\text { as per Element } \mathrm{B} \text {. }\end{array}$ \\
\hline e) Framework verification & Interview & $\begin{array}{l}\text { Senior managers involved in } \\
\text { the mobile initiative }\end{array}$ \\
\hline
\end{tabular}

To assess the feasibility of each metric (see Figure One), a document analysis was employed. This is a research method that may be applied in order to make replicable and valid references from data to their context (Krippendorf, 1980), in this case the identification of metrics from relevant internal documentation to analyse the performance of mobile technologies. Compared to interviewing or questionnaires, this method is unobtrusive and therefore may provide a more holistic set of metrics (Robson, 2002).

Following the feasibility analysis, an information map was created. An information map is a method for representing an organisation's knowledge, in terms of the information types and sources (Klein and Prusak, 2004). In short, it allows organisations to depict where information exists (Stewart, 1994). Such a method may prove useful in representing metrics and their sources. The feasible metrics were then placed into a template scorecard via a review of existing literature on the application of the balanced scorecard in the policing domain.

The framework incorporates desk research in order to collate information from specific sources of information, as examined via the information map. Desk research or secondary analysis usually entails the analysis of existing quantitative data. Since information already exists on the specific metrics (identified in the feasibility analysis), this method may allow 
more time to be spent on the analysis and interpretation of data, rather than on the data gathering exercise itself (Bryman, 2008), which is relevant given the short timescales available.

\subsection{Findings: Framework to Assess the Value of Mobile Policing}

\subsection{Feasibility analysis of metrics}

The first part of the framework is to examine the feasibility of metrics. Table two shows all of the metrics considered, identified from document analysis of internal reports, emails, NPIA documentation, guidance and workshops, along with the source of the metric (such as a national metric from the Home Office or an internal metric from a police force), and the feasibility of each metric. It shows police forces in which areas they should concentrate their efforts when assessing the value of mobile technologies.

In terms of feasibility, data is available and can be collated for metrics one to eight. These metrics are also considered to be influenced by the impact of mobile technologies. For metric nine, the resources required to collate the time spent on visible frontline policing may prove to be too large for police forces. Instead, data from metric one (time out of station) should be used. It may be argued that the number of complaints (metric 10) and more appropriate arrests (metric 11) are not directly attributed to the usage of mobile technologies, and are more likely to be influenced by additional external variables. Metric number 12 (level of timely information) is a national NPIA metric, and links in with the outcomes of the study into back office data entry volumes (as per metric ten). The level of training was considered as a key metric in relation to learning and development for mobile information technologies, but most of the training courses were conducted prior to 2008, which is before the time-span of the assessment period. Within this study, data were sought to assess any potential changes in the number of IT resources, in particular fixed desktop computers within local policing units. However, due to the small levels of auditing of hardware these data were unavailable. 
Table 2: Feasibility analysis of metrics to assess value of mobile policing

\begin{tabular}{|c|c|c|c|}
\hline 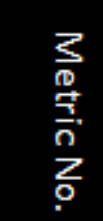 & $\begin{array}{c}\text { Source } \\
\text { (Internal } \\
\text { or } \\
\text { National) }\end{array}$ & Metric details & 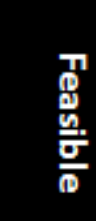 \\
\hline 1. & National & $\begin{array}{l}\text { Time out of station for response officers with mobile device and } \\
\text { neighbourhood officers with Blackberry }\end{array}$ & Yes \\
\hline 2. & National & $\begin{array}{l}\text { Number of return trips and mileage to base police stations for } \\
\text { vehicles with mobile devices }\end{array}$ & Yes \\
\hline 3. & National & $\begin{array}{l}\text { Level of usage of mobile devices (e.g. number of data packets } \\
\text { transferred via mobile devices; CIS usage on MDT) }\end{array}$ & Yes \\
\hline 4. & $\begin{array}{l}\text { National } \\
\text { \& internal }\end{array}$ & $\begin{array}{l}\text { Number of appointments made and kept (e.g. scheduled } \\
\text { responses) }\end{array}$ & Yes \\
\hline 5. & National & Number of Airwave transactions to exchange information & Yes \\
\hline 6. & National & Level of fixed desktop computers & Yes \\
\hline 7. & Internal & $\begin{array}{l}\text { Level of public confidence through anticipated increased visibility } \\
\text { levels }\end{array}$ & Yes \\
\hline 8. & National & Back office data entry volumes and resourcing levels & Yes \\
\hline 9. & National & Level of visible frontline policing & No \\
\hline 10. & National & Number of complaints & No \\
\hline 11. & National & More appropriate arrests & No \\
\hline 12. & \begin{tabular}{l|} 
National \\
\& internal
\end{tabular} & Level of timely information & No \\
\hline 13. & Internal & Level of training for mobile technologies & No \\
\hline 14. & Internal & Level of IT infrastructure for mobile technologies & No \\
\hline
\end{tabular}

\subsection{Information map}

The data gathering phase of the framework is based on secondary data. The second stage of the framework is to map the metrics (Table Two) to their specific file location via an information map as shown by Figure Two. The information types (metrics) are shown on the left and the sources of each metric are shown on the right. 


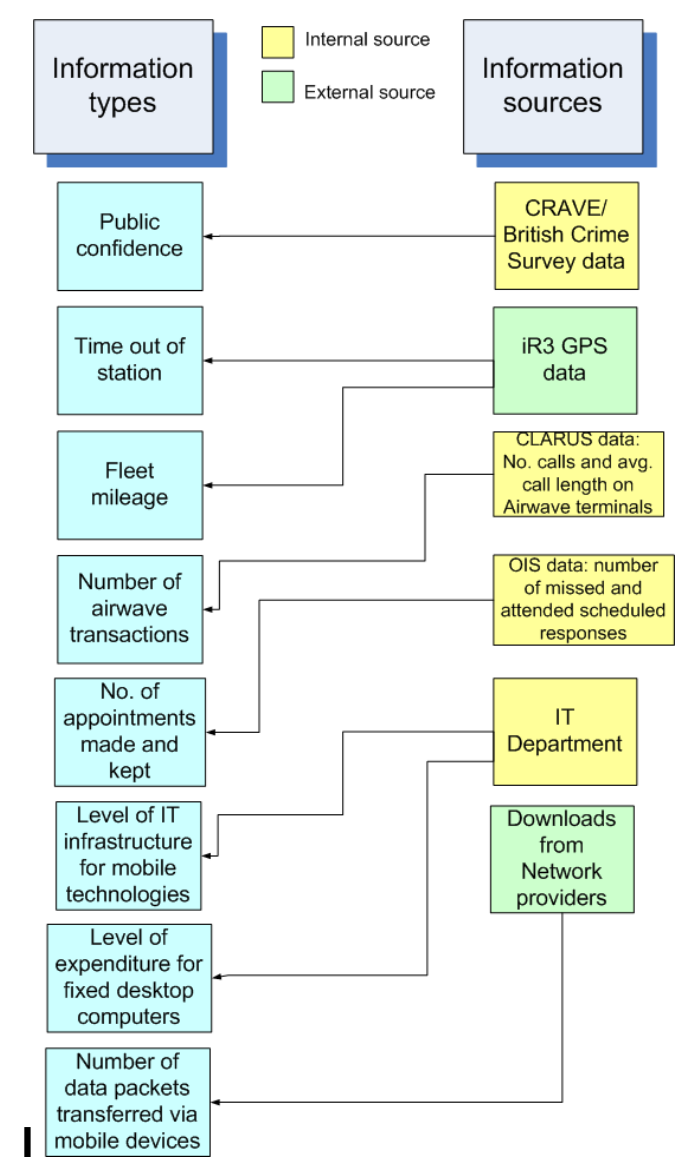

Figure Two: Information map of metrics and locations of metrics

The information sources already exist within most UK police forces and are therefore readily available to collate data to assess value. This is a key element within the proposed framework. For example, all police forces in the UK collect data in relation to public satisfaction and confidence via the Confidence, Reassurance, Accessibility and Visibility Evaluation (CRAVE) and British Crime surveys, and specifically ask questions in the survey such as whether the level of police patrolling in an area changed in the past 12 months. From this, it may be possible to deduce whether through using mobile devices the level of policing presence has increased, which may thus lead to a rise the level of satisfaction amongst members of the public.

Similarly, theoretically speaking, information is more widely accessible via a mobile device and so the level of usage and reliance on Airwave terminals to obtain information for the allocation of incidents should decrease. To assess whether this is the case, the framework proposes that data are collated from a management information tool that allows analysis of call data records over time from Airwave radio terminals for both voice and data activity. All police forces have such a system and in some forces, a system known as 'CLARUS' is used. Again, this allows the reuse of existing information in a short timeframe.

Another important indicator of mobile technologies is its impact on the number of scheduled appointments made and the number of appointments kept. Prior to the introduction of mobile technologies, incidents were allocated via a point-to-point facility on an Airwave radio terminal. However, there were often delays in doing this, especially when the Airwave network was busy. In addition, scheduling slots with members of the public was less effective because time slots were not as specific. To assess for any change in 
the numbers of scheduled responses, the framework advises that secondary data are gathered from an internal operational intelligence system, which contains incident data in relation to the number of missed and attended scheduled responses over a specific time period.

Traditionally, police forces have invested a large amount of time and energy into collating primary data to examine the level of time spent out of police stations and the level of mileage associated with travelling to and from base stations. This has typically involved the use of diaries, interviews, direct observations and time and motion studies to analyse activities performed by police officers (for example as previously employed in studies by Home Office, 2001 and Lindsay et al, 2009). Alternatively, the use of resource and demand systems is being introduced by a handful of police forces as an innovative means of collecting similar data (for example Leach, 2009 and Taylor, 2010). This works by mapping in real time where incidents are taking place and is linked to automatic tracking devices for vehicles and Airwave radios, which in turn shows where a vehicle of officer has spent their time throughout a shift (Flanagan, 2008). The framework recommends that using such an approach can offer a new perspective to performance assessment in the policing domain. It provides objective evidence compared to similar qualitative studies, and therefore may allow a more concrete examination of the impact of mobile technologies on policing activities. For police forces that already have such systems in place, this can minimise the amount of time and effort needed to obtain relevant data.

The level of usage of mobile technologies is a key measure to improving the performance of the overall mobile information initiative. The framework suggests that such data is accumulated from the crime and intelligence system (CIS), which shows the total crimes created and viewed in CIS on a mobile device. Mobile crime recording is a key driver to reducing the level of paper-based bureaucracy and it is therefore important to assess to what extent it is being used. In addition, further data can be assembled from mobile network providers. Specifically, the number of data packets, that is a unit of information sent and received over the network for mobile devices can be obtained. This may give a more general picture of device usage. Overall, these various information sources offer a unique approach to assess the value of the mobile initiative. They are certainly a step away from the traditional means of relying on return on investment, for example. Having identified a range of suitable and feasible measures and related accessible information, it is important to represent this information in a structured manner. This is discussed in the next section.

\subsection{Mobile technologies scorecard}

As discussed in the 'Context' section of this paper, the number of indicators available within this framework may cause information overload to decision-makers. In order to overcome this, effective representation and dissemination of information is critical. Consequently, the balanced scorecard was applied to the final part of the framework as a template to illustrate information in a single document. The template scorecard is shown in Table 3. 
Table 3: Template mobile policing scorecard

\begin{tabular}{|c|c|c|c|}
\hline \multicolumn{4}{|c|}{ Balanced Scorecard Measures: Mobile Technologies } \\
\hline \multicolumn{2}{|c|}{ Customers } & \multicolumn{2}{|c|}{ Internal processes } \\
\hline $\begin{array}{l}\text { Action } \\
\text { 1. Increase level of } \\
\text { public confidence }\end{array}$ & \begin{tabular}{|l}
\multicolumn{1}{c}{ Measures } \\
a) \\
Change in \\
customer \\
satisfaction \\
through providing \\
service with \\
mobile \\
technologies
\end{tabular} & 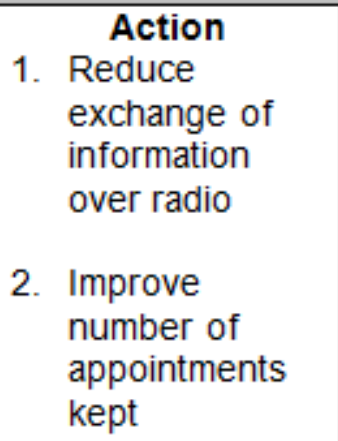 & $\begin{array}{l}\text { Measures } \\
\text { a) Change in the total } \\
\text { number of voice } \\
\text { transactions over } \\
\text { radio } \\
\text { b) Change in number } \\
\text { of diarised } \\
\text { appointments } \\
\text { made and kept }\end{array}$ \\
\hline \multicolumn{2}{|c|}{ Continuous improvement } & \multicolumn{2}{|c|}{ Financial } \\
\hline $\begin{array}{l}\text { Action } \\
\text { 1. To develop the IT } \\
\text { infrastructure for } \\
\text { mobile } \\
\text { technologies }\end{array}$ & 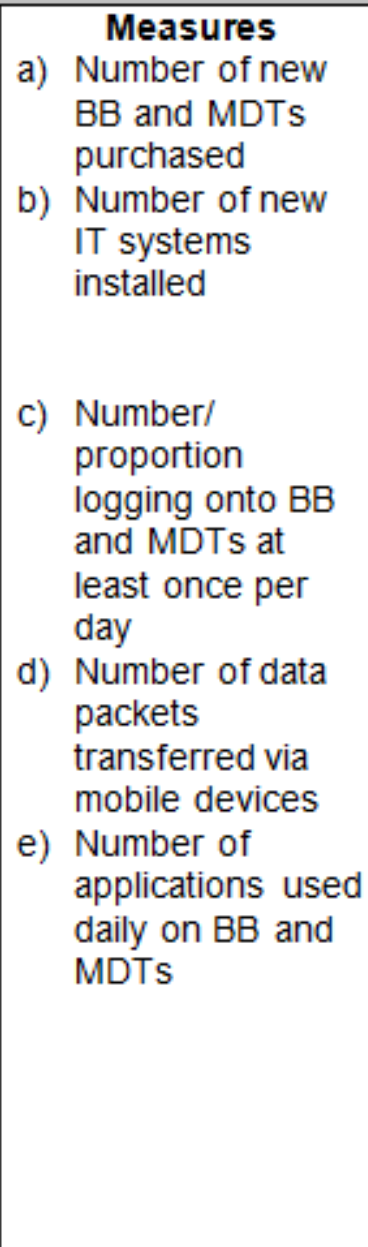 & $\begin{array}{l}\text { 3. } \begin{array}{l}\text { Change in } \\
\text { number of back } \\
\text { office staff }\end{array} \\
\text { 4. Reduction in } \\
\text { investigation } \\
\text { time/ direct } \\
\text { input of crime } \\
\text { reports } \\
\text { 5. Increase } \\
\text { efficient use of } \\
\text { fleet vehicles }\end{array}$ & $\begin{array}{l}\text { Measures } \\
\text { a) Level of time spent } \\
\text { on patrol for BB \& } \\
\text { MDT users (iR3 } \\
\text { data) } \\
\text { b) Change in budget } \\
\text { allocation for } \\
\text { desktop computers } \\
\text { c) Reduction in police } \\
\text { estates through } \\
\text { putting MDTs in } \\
\text { community } \\
\text { d) Reduction in cost } \\
\text { of hard-wiring } \\
\text { computers through } \\
\text { putting MDTs in the } \\
\text { community } \\
\text { e) Time to record } \\
\text { crime on paper } \\
\text { versus electronic } \\
\text { recording (see } \\
\text { WP3.3) } \\
\text { f) Change in number } \\
\text { of crime inputters in } \\
\text { the Force } \\
\text { g) Change in level of } \\
\text { mileage for MDT- } \\
\text { based vehicles }\end{array}$ \\
\hline
\end{tabular}




\subsection{Verifying the assessment framework for the Policing domain}

The results of the interviews with senior management involved in the mobile initiative from a single UK police force suggested that the framework was well received. It was advocated that the feasibility analysis element of the framework made it clearer for police forces to know where to concentrate their efforts, and compared with other national guidance it provided a stronger starting point to begin a performance assessment exercise. The findings from the verification also suggested that the information map within the framework allowed a good understanding of how and where specific data can be collated.

Participants indicated that the scorecard element of the framework may allow greater simplicity and visual representation than statistical presentation of information. This can make it difficult for management to interpret the value of an initiative at a glance. It was also implied that it can reduce the need to read through a mass of information about the performance of the mobile initiative in order to arrive at a final conclusion. Instead the framework integrates all the information into a single page. Findings from the interviews suggested that management were also favourable towards the alternative perspectives, and felt that it could provide a more holistic analysis of the value of mobile technologies than an approach that did not incorporate a theoretical element from existing literature. This may prove beneficial when justifying continued investment of the initiative to relevant funding bodies. The findings here may also imply that the framework may be valid to other initiatives, with some adaptation of measures.

Overall, the findings suggest that the framework was well received by management. This is mirrored in findings in the Dumfries and Galloway Police, where, as discussed previously, historically their approach was to develop appropriate operational plans for dealing with a single initiative (such as drink driving) and collect basic performance information (Wisniewksi and Dickson, 2001). Rather, application of the scorecard element was deemed successful by the team that applied it and the Force as a whole, and this provided a more robust and comprehensive means to examine performance (Ibid.). Similarly, in the Portuguese police service the use of the scorecard element showed to improve performance measurement (Gomes et al, 2006, 2007), and there was a genuine acceptance of the scorecard process in local authorities to add value to what local services are achieving for their communities (Wisniewski and Olafsson, 2004). This could suggest that the framework may prove to be effective in other organisations about to or already implementing a similar mobile initiative. Further research may seek to apply the framework within different contexts to test the validity of this statement.

\subsection{Conclusion}

This paper has developed a conceptual framework to assess the value of mobile data technologies in policing. Collation of performance related data within a short time frame with little effort or budget is an important consideration. At present there are few structured frameworks from which police forces can apply to achieve this. This conceptual framework contributes to the arena of performance assessment in policing by making it clearer for police forces to understand where to concentrate their efforts, in terms of what data to collect within an evaluation.

The framework argues for feasible metrics to be based on secondary data sources, which mostly already exist within police information systems, such as level of radio transactions from a common management information tool that allows analysis of call data records over 
time. Compared with previously utilised data collection methods, such as direct observation, secondary research permits collation of evidence within limit time and budget constraints. Furthermore, the framework offers a new perspective to efficiency evaluation by employing a resource and demand management information system to examine the level of time spent in communities. Compared to similar qualitative studies, tracking the location of police officers through global positioning systems can provide more objective data and thus a more concrete examination of the impact of mobile technologies on policing activities. A combination of these methods will lead to next generation enhancement to performance measurement in policing.

Traditionally in policing, evaluation of initiatives has centred on financial elements. The framework augments previous approaches by offering a more holistic collection of metrics via a theoretical method of the balanced scorecard, which has shown to be one of the most applicable evaluation methods within the public sector. Whilst the balanced scorecard has been applied to a handful of studies in policing, there has not yet been an adaptation to suit the mobile business terminal initiative. Feedback from management within a UK police force demonstrated that the adapted scorecard was well received, due to the approach and dissemination of results into a single document. In summary, the conceptual framework is readily utilisable to police forces looking to assess new technological initiatives.

\subsection{References}

Barton, L. C. and Barton, H. (2011). Challenges, issues and change: what's the future for UK policing in the twenty-first century? International Journal of Public Sector Management, 24(2), 146-156.

Boland, T. and Fowler, A. (2000). A systems perspective of performance management in public sector organisations. International Journal of Public Sector Management, 13(5), 417-446.

Boyne, G., et al. (2004). Explicit reforms, implicit theories and public service improvement, Public Management Review, 6(2), 211-28.

Bryman, A. (2008). Social research methods. Oxford University Press: Oxford.

Collier, P. M. (2006). In search of purpose and priorities: police performance indicators in England and Wales. Public Money and Management, 26(3), 165-172.

Couillard, J., et al. (2009). The logical framework approach - millennium. Project Management Journal, 40(4), 31-44.

Davies and Hart (2005). The 'Most Significant Change' (MSC) Technique: A guide to use. United Kingdom: CARE International.

European Commission. (2004). Project cycle management guidelines.

http://ec.europa.eu/europeaid/multimedia/publications/documents/tools/europeaid adm pc $\underline{m}$ guidelines 2004 en.pdf, 01.03.04, [accessed 24.03.11]

Flanagan, R. (2008). The review of policing: interim report. http://police.homeoffice.gov.uk/publications/policereform/Review of Policing Interim 1.pd f?view=Binary, 11.01.08, [accessed 09.06.08]. 
Gomes, P. S., et al. (2006). Performance measurement of the Portuguese Police Force using the Balanced Scorecard. In: Proc. of $4^{\text {th }}$ International Conference on Accounting, Auditing and Management in Public Sector Reforms, 2006, Siena, Italy, p. 1-25.

Gomes, P. S., et al. (2007). Use of performance measurement in the public sector: the case of the police service. In: Proc. of $11^{\text {th }}$ Biennial CIGAR Conference, 2007, Coimbra: Portugal, p. 1-21.

Home Office. (2001). Diary of a Police Officer. Police Research Series: Paper 149. [available at http://rds.homeoffice.gov.uk/rds/prgpdfs/prs149.pdf], [accessed 31.03.2011].

Home Office. (2008). Policing Green Paper.

http://files.homeoffice.gov.uk/police/policing green paper.pdf, 17.07.08, [accessed 25.11.09].

Ilston, G. (2010). "Policing bears brunt of Home Office cuts", Police Professional, 27 May, [online], http://www.policeprofessional.com/news.aspx?id=10492, [accessed 17.03.2011].

Kaplan, R. S. and Norton, D. P. (1992). The Balanced Scorecard - measures that drive performance. Harvard Business School: Boston, MA.

Klein, D. A. \& Prusak, L. (2004). Characterising intellectual capital: mastering the information environment program working paper. Centre for Information Technology. Ernst and Young: Boston.

Krippendorf, K. (1980). Content analysis: an introduction to its methodology. Sage: California.

Leach, B. (2009). "Metropolitan police officers to be tracked by GPS", Telegraph, 6 July, [online], http://www.telegraph.co.uk/technology/news/5753346/Metropolitan-Policeofficers-to-be-tracked-by-GPS.html, [accessed 11.03.2011].

Lindsay, R., et al. (2009). The impact of mobile technology on a UK police force and their knowledge sharing. Journal of Information and Knowledge Management, 8(2), 101-112.

Madan, R. (2007). Demystifying Outcome measurement in Community Development: Fellowship Programs for Emerging leaders in Community and Economic Development.

Modell, S. (2001). Performance measurement and institutional processes: a study of managerial responses to public sector reform. Management Accounting Research, 12, 437- 464.

Moore, M. (2003). The public value scorecard: a rejoinder and an alternative to 'strategic performance measurement and management in non-profit organizations' by Robert Kaplan, Kennedy School of Government, The Hauser Center for Nonprofit Organizations, Harvard University, Boston, MA, Working Paper No. 18.

Office of Justice Programs. (2011). Center for program evaluation and performance measurement. http://www.ojp.usdoj.gov/BJA/evaluation/glossary/glossary p.htm, 2011, [accessed 21.03.2011]. 
Pollitt, C. and Bouckaert, G. (2000). Public Management Reform: A Comparative Analysis. Oxford University Press: Oxford.

Renshaw, J. (2006). TOOLS for improving outcomes and performance: comparing six different approaches. IDeA: London.

Robson, C. (2002). Real world research: a resource for social scientists and practitionerresearchers. Blackwell: Oxford.

Savvas, A. (2008). "Police get $£ 25$ million for handhelds", Computer Weekly, 23 July, [online], http://www.computerweekly.com/Articles/2008/07/23/231606/police-get-25-millionfor-handhelds.htm, [accessed 21.03.2011].

Shane, J. M. (2010). Performance management in police agencies: a conceptual framework. Policing: An International Journal of Police Strategies and Management, 33(1), 6-29.

Smutylo, T. (2005). "Outcome Mapping: A method for Tracking Behavioural Changes in Development Programs", Institutional Learning and Change, August 2005, [online], http://ageconsearch.umn.edu/bitstream/52517/2/ILAC Brief07 mapping.pdf, [accessed 21.03.2011].

Stewart, T. A. (1994). Your company's most valuable asset: intellectual capital. Fortune, 130(7), 70.

Taylor, J. (2010). "Leicestershire police use technology to cut anti-social behaviour", Computer Weekly, 19 January, [online],

http://www.computerweekly.com/Articles/2010/01/19/240010/Leicestershire-police-usetechnology-to-reduce-anti-social.htm\#, [accessed 11.04.2011].

Ward, J. and Daniel, E. (2006). Benefits Management, Delivering value from IS \& IT Investments. Wiley: Chichester.

Wisniewski, M. and Dickson, A. (2001). Measuring performance in Dumfries and Galloway Constabulary with the Balanced Scorecard. Journal of the Operational Research Society, 52(10), 1057-1066.

Wisniewski, M. and Olafsson, S. (2004). Developing balanced scorecards in local authorities: a comparison of experience. International Journal of Productivity and Performance Management, 53(4), 602-610. 